\title{
Sinop’ta 2012-2013 Avcılık Sezonunda Satışa Sunulan Balık Türlerinin Fiyat Yönünden İncelenmesi
}

\author{
Şennan Yücel*, Birol Baki, Muhittin Kasa, Fatma Demir \\ Sinop Üniversitesi, Su ürünleri Fakültesi, Balıkçılık Temel Bilimleri Anabilim Dalı, 57000 Sinop, Türkiye
}

M A K A L E B İ L G İ S İ

Araştırma Makalesi

Geliş 04 Mayıs 2017

Kabul 25 Temmuz 2017

Anahtar Kelimeler:

Karadeniz

Sinop

Balık türleri

Fiyat

Avcilık

*Sorumlu Yazar:

E-mail: syucel@ sinop.edu.tr

\section{Ö Z E T}

Bu çalışmada 2012 Mayıs-2013 Nisan av sezonunda Sinop'ta perakende balık satışı yapan merkezlerden alınan bilgiler kapsamında satışa sunulan balık türleri ile fiyatlarının aylık dağılımının belirlenmesi amaçlanmıştır. İşletmeler satış yerlerinde satılan balık türleri ve satış hacimlerine göre; I (en çok), II (orta) ve III (en az) olarak sınıflandırılmıştır. Her grubu temsil edecek ikişer perakende balık satış yeri olmak üzere toplamda altı ayrı satış yeri, amaçlı örnekleme yöntemi ile tespit edilmiştir. Satış yerlerinden araştırma süresince her ay ve ayda iki kez günün aynı saatinde balık türleri ile fiyatları alınmıştır. Yapılan çalışmada satış merkezlerinde hamsi (Engraulis encrasicolus ponticus), istavrit mackerel (Trachurus trachurus), lüfer (Pomatomus saltatrix), palamut (Sarda sarda), tirsi (Alosa fallax nilotica), zargana (Belone belone), kefal (Mugil cephalus), eşkina (Sciana umbra), kırlangıç (Trigla lucerna), kalkan (Psetta maxima), barbunya (Mullus barbatus), mezgit (Merlangus merlangus), iskorpit (Scorpaena porcus), minekop (Umbrina cirrosa), karagöz (Diplodus vulgaris), isparoz (Diplodus annularis), izmarit (Maena smaris), kaya balığı (Gobius niger) türlerinin satışının yapıldı ğ 1 belirlenmiştir. Ekonomik değeri yüksek olan türlerden hamsi, lüfer, palamut ve kalkan balıklarının fiyatı örnekleme istasyonları arasında farklılık gösterirken, istavrit, barbunya ve mezgit balığının fiyatı farklılık göstermemiştir. Yıllara dayalı fiyatlara bakıldığında 2012-2013 yılı Sinop ili istavrit, lüfer, palamut, barbunya, mezgit balığı fiyatlarının 2008-2012 yılı ortalama fiyatlarına yakın, hamsi ve kalkan balığı fiyatlarının ise yüksek olduğu tespit edilmiştir.

Turkish Journal Of Agriculture - Food Science And Technology, 5(11): 1290-1294, 2017

Examination of the Fish Price Offered for Sale During 2012-2013 Fishing Season in Sinop, Turkey

\begin{tabular}{l} 
A R T I C L E I N F O \\
Research Article \\
Received 04 May 2017 \\
Accepted 25 July 2017 \\
\hline
\end{tabular}

Keywords:

Black Sea

Sinop

Fish species

Price

Fishing

\section{*Corresponding Author:}

E-mail: syucel@sinop.edu.tr

\section{A B S T R A C T}

The aim of the study was to determine the monthly price distribution of the offered fish species for sale within the scope of information received from the centers engaged in the sale of retail fish during 2012-2013 fishing season in Sinop, Turkey. The enterprises were grouped as I (the most), II (middle) and III (the least) according to the sales volume and fish species. Each group was represented by two different fish enterprise and so a total of six separate enterprises were determined by purpose sampling method. During the study, sale prices and fish species were obtained twice every month at the same time of day. It was determined that anchovy (Engraulis encrasicolus ponticus), horse mackerel (Trachurus trachurus), bluefish (Pomatomus saltatrix), atlantic bonito (Sarda sarda), twait shad (Alosa fallax nilotica), needlefish (Belone belone), mullet (Mugil cephalus), shi drum (Umbrina cirrosa), brown meagre (Sciana umbra), common two-banded seabream (Diplodus vulgaris), annular bream (Diplodus annularis), tub gurnard (Trigla lucerna), picarel (Maena smaris), turbot (Psetta maxima), red mullet (Mullus barbatus), whiting (Merlangus merlangus), scorpion fish (Scorpaena porcus), goby (Gobius niger) were offered for sale in fish markets. While the prices of higher economic valued fish species like anchovy, bluefish, atlantic bonito and turbot prices were different between the enterprises, the prices of horse mackerel, red mullet and whiting species were not different. When considering the fish prices based on years, the prices of horse mackerel, bluefish, atlantic bonito, red mullet and haddock during 2012-2013 years were close to the average price of 2008-2012 years and the prices of anchovy and turbot during 20122013 years were higher than the average price of 2008-2012 years in Sinop. 


\section{Giriş}

Dünyada nüfus artışı ile birlikte, besin ihtiyacı da artmaktadır. Dolayısı ile günümüz insanı besin ihtiyacını gidermek ve beslenme sorunlarını en alt düzeye indirmek için tüm kaynaklardan en üst düzeyde yararlanmaya çalışmaktadır.

Mevcut kaynaklar nüfus artışından doğan besin ihtiyacını karşılama konusunda yetersiz kalmaktadır. Sürdürülebilir kaliteli ve sağlıklı bir yaşam için, alternatif besin kaynakları arasında ve hayvansal protein açısından beslenmede önemli bir yere sahip olarak su ürünleri gelmektedir (Aydın ve Karadurmus, 2012). Toplumsal alg1 olarak tüketilen gidaların yeterli ve dengeli beslenmede önemli bir yer tuttuğu hususu, çok sayıda bilimsel araştırma sonuçları ile de desteklemektedir.

Diğer yandan günlük protein ihtiyacının üçte birinin hayvansal kaynaklardan alınmasının gerekliliğinden (Hanta, 1994; Büyüknisan, 2008) dolayıdır ki; geçmişi insanlığın tarihi kadar eski olan et, zamanla toplumların en önemli gıda maddesi olmuştur (Arıtaşı, 2009). Ayrıca omega-3 ve omega-6 yağ asitleri, koroner kalp hastalıkları ve kanser gibi bazı önemli hastalıklara karşı koruma sağlaması da su ürünlerini daha da vazgeçilmez hale getirmektedir (Atar ve Alçiçek, 2009; Kaba ve Çorapc1, 2014).

Besin değerinin fazla, sindiriminin kolay ve insanların dengeli beslenmesinde etkili besin kaynağı olması nedeniyle, insanların kaliteli besin ihtiyacının bir kısmının su ürünlerinden karşılanmasını adeta zorunlu kılmaktadır. $\mathrm{Bu}$ amaçla su ürünleri üretimi ile tüketimi arasındaki planlamaların ciddi olarak yapılıp, sürdürülebilir stratejiler oluşturulmalıdır. Planlama yapılabilmesi için ise mevcut durumun tespit edilmesi ve elde edilecek verileri doğru yorumlamak gerekmektedir.

Ülkemiz su ürünleri sektöründen bahsedildiğinde, ilk akla gelen avcılık üretimidir. Ülkemiz 2013 yılı su ürünleri üretiminin \%61,6’sını deniz ve içsularda avcılık üretimi, \%38,4'ü deniz ve içsularda yetiştiricilik yolu ile üretim oluşturmaktadır (TUIK, 2014). Toplam deniz balıkları avcılık üretiminin \%49,7'si Doğu Karadeniz, \%17'si Batı Karadeniz olmak üzere \%66,7'lik oranı Karadeniz Bölgesinden sağlanmaktadır. 2012 yılı 644.852 tonluk üretimin 532.346,7 tonluk bölümü iç tüketime sunulmuş ve yıllık kişi başı tüketim miktarı 7,081 kg olarak gerçekleşmiştir (TUİK, 2013).

Su ürünleri dağıtım sisteminde önemli yeri olan balık satış yerleri; hem balıkçılık yönetimi hem de satılan ürünlerin boy yasakları, tazelik, hijyen ve gıda güvenilirliğinin kontrol edilebilirliği bakımından da önemlidir. Diğer yandan perakende satış yerleri, üretilen balıkların tüketiciye ulaşmasındaki tüm çabaları kapsar ve kısaca üretim ile tüketim arasındaki bağlantıyı sağlar.

Araştırmada Karadeniz balıkçılığında önemli bir yere sahip olan Sinop balıkçılığının pazara arzı incelenmiştir. Bu amaçla 2012-2013 yılı av sezonunda perakende balık satış yerlerinin yetkilileri ile yapılan karşılıklı görüşmeler sonucu elde edilen bulgulara dayanılarak aylık dağılımın belirlenmesi amaçlanmıştır.

\section{Materyal ve Metot}

$\mathrm{Bu}$ çalışmada 2012 Mayıs-2013 Nisan avcılık sezonunda Sinop'ta perakende balık satış yerlerinde satışa sunulan balık türleri ile balık satışlarının ortalama fiyat dağılımı belirlenmeye çalışılmıştır. Örnekleme dahil olacak perakende balık satış yerleri, tabakalı amaçlı örnekleme yöntemi ile belirlenmiştir. Balık satış yerleri, balık satış hacimlerine göre I (en çok), II (orta) ve III (en az) olarak gruplandırılmıștır. Her grupta iki farklı istasyon örnekleme dahil edilerek, kitlenin $\% 50$ oranında temsil edilmesi sağlanmıștır.

Perakende balık satış yerlerinde araştırma süresince ayda iki kez günün aynı saatinde türlere ait fiyatlar elde edilmiş, veriler aylık ortalama \pm sd olarak hesaplanarak, balık türlerine göre karşılaştırmalı olarak incelenmiştir.

Günlük olarak satılan balık miktarları kişisel beyana dayalı olarak alınmıştır. Üretimde olduğu gibi balık satış yerlerindeki satılan balık miktarları sağlıklı bir şekilde kayıt altına alınmadığından, balık miktarları sözlü beyanlar esas alınarak araştırma sürecince kaydedilmiş fakat araştırmada dikkate alınmamıştır. Perakende balık satış istasyonları arasındaki fiyat farklılığı tek yönlü varyans analizi (ANOVA) Minitab for Windows 17 ve Microsoft Excel 2010 programlarında değerlendirilmiştir.

\section{Bulgular ve Tartışma}

Çalışmada, Sinop ilinde belirlenen perakende balık satış yerlerinde 2012 Mayıs-2013 Nisan aylarında satışa sunulan balık türleri ve ortalama satış fiyatları tespit edilmiştir.

Araştırma sürecinde perakende balık satış yerlerinde satışa sunulan balık türlerinin aylık olarak dağılımı Tablo 1 'de verilmiştir.

Çalışmada, ekonomik değeri fazla olan ve önemli türlerden hamsi (Engraulis encrasicolus ponticus, Aleksandrov, 1927), istavrit (Trachurus trachurus, L.,1758), lüfer (Pomatomus saltatrix, L., 1766), palamut (Sarda sarda, Bloch, 1793), kalkan (Psetta maxima, L., 1758), barbunya (Mullus barbatus, L., 1758) ve mezgit (Merlangius merlangus) balıklarının satış zamanı ve işletmelerdeki satış fiyatları değerlendirilmesi ayrıntılı olarak yapılmıştır (Tablo 2).

Diğer türler ise; İskorpit (Scorpaena porcus); Şubat, Nisan, Mayıs, Haziran, Temmuz, Ağustos, Ekim ve Aralık aylarında, temizlenmiş olarak (18,0-30,0 TL/kg), Eşkina (Sciaena umbra); Nisan, Mayıs, Haziran, Ağustos, Ekim ve Kasım aylarında (9,0-20,0 TL/kg), İsparoz (Diplodus annularis); Nisan, Mayıs, Haziran, Ağustos, Ekim ve Kasım aylarında (4,0-5,0 TL/kg), İzmarit (Maena smans); Ocak, Nisan, Mayıs ve Ağustos aylarında (2,5$11,5 \mathrm{TL} / \mathrm{kg}$ ), Karagöz (Diplodus vulgaris); Mayıs ve Ekim aylarında (15,0-17,5 TK/kg), Kaya Balığı (Gobius niger); Ocak ve Nisan aylarında (3,5-5,5 TL/kg), Kefal (Mugil cephalus); Şubat-Mart ayları dışındaki tüm aylarda (3,0-14,0 TL/kg), Kırlangıç (Triglia lyra); Ocak, Nisan, Mayıs, Ağustos, Ekim, Kasım ve Aralık aylarında (15,040,0 TL/kg), Kötek-Minekop (Umbrna cirrosa); Ocak ve Nisan aylarında (20,0-30,0 TL/kg), Tirsi (Alosa agone); Ocak, Şubat, Mart, Ekim, Kasım ve Aralık aylarında (2,515,0 TL/kg), Zargana (Belone belone); Ekim-Şubat aylarında $(7,5-13,0 \mathrm{TL} / \mathrm{kg})$ arasında satışa sunulduğu belirlenmiştir. 
Tablo 1 Satıșa Sunulan Balık Türlerinin Dağılımı

\begin{tabular}{|c|c|c|c|c|c|c|c|c|c|c|c|c|}
\hline \multirow{2}{*}{ Türler } & \multicolumn{8}{|c|}{2012} & \multicolumn{4}{|c|}{2013} \\
\hline & May. & Haz. & Tem. & Ağu. & Eyl ül & Eki. & Kas. & Ara. & Oca. & Şub. & Mar. & Nis an \\
\hline Hamsi Engraulis encrasicolus ponticus & & & & & & $\mathrm{x}$ & $\mathrm{X}$ & $\mathrm{x}$ & $\mathrm{X}$ & $\mathrm{X}$ & $\mathrm{x}$ & $\mathrm{x}$ \\
\hline İstavrit Trachurus trachurus & $\mathrm{x}$ & $\mathrm{X}$ & & $\mathrm{x}$ & $\mathrm{X}$ & $\mathrm{x}$ & $\mathrm{x}$ & $\mathrm{x}$ & $\mathrm{x}$ & $\mathrm{x}$ & $\mathrm{x}$ & \\
\hline Lüfer Pomatomus saltatrix & & & & $\mathrm{x}$ & $\mathrm{x}$ & $\mathrm{x}$ & $\mathrm{x}$ & $\mathrm{x}$ & $\mathrm{x}$ & & & \\
\hline Palamut Sarda sarda & & & & $\mathrm{x}$ & $\mathrm{x}$ & $\mathrm{x}$ & $\mathrm{x}$ & $\mathrm{x}$ & $\mathrm{X}$ & & & \\
\hline Tirsi Alosa fallax nilotica & & & & & & $\mathrm{x}$ & $\mathrm{x}$ & $\mathrm{x}$ & $\mathrm{x}$ & $\mathrm{x}$ & $\mathrm{x}$ & \\
\hline Zargana Belone belone & & & & & & $\mathrm{x}$ & $\mathrm{x}$ & $\mathrm{x}$ & $\mathrm{x}$ & $\mathrm{x}$ & & \\
\hline Kefal Mugil cephalus & $\mathrm{x}$ & $\mathrm{X}$ & $\mathrm{x}$ & $\mathrm{x}$ & $\mathrm{x}$ & $\mathrm{x}$ & $\mathrm{x}$ & $\mathrm{x}$ & $\mathrm{x}$ & & & $\mathrm{x}$ \\
\hline Kötek-Minekop Umbrina cirrosa & & & & & & & & & $\mathrm{x}$ & & & $\mathrm{x}$ \\
\hline Eşkina Sciana umbra & $\mathrm{x}$ & $\mathrm{X}$ & & $\mathrm{x}$ & & $\mathrm{x}$ & $\mathrm{x}$ & & & & & $\mathrm{x}$ \\
\hline Karagöz Diplodus vulgaris & $\mathrm{x}$ & & & & & $\mathrm{x}$ & & & & & & \\
\hline İsparoz Diplodus annularis & & & & & & $\mathrm{x}$ & $\mathrm{x}$ & $\mathrm{X}$ & & & & \\
\hline Kırlangıç Trigla lucerna & $\mathrm{x}$ & & & $\mathrm{x}$ & & $\mathrm{x}$ & $\mathrm{x}$ & $\mathrm{x}$ & $\mathrm{x}$ & & & $\mathrm{x}$ \\
\hline İzmarit Maena smaris & $\mathrm{x}$ & & & $\mathrm{x}$ & & & & & $\mathrm{X}$ & & & $\mathrm{x}$ \\
\hline Kalkan Psetta maxima & & & & & $\mathrm{x}$ & $\mathrm{x}$ & $\mathrm{x}$ & $\mathrm{x}$ & $\mathrm{x}$ & $\mathrm{x}$ & $\mathrm{x}$ & $\mathrm{x}$ \\
\hline Barbunya Mullus barbatus & $\mathrm{x}$ & $\mathrm{x}$ & & $\mathrm{x}$ & $\mathrm{x}$ & $\mathrm{x}$ & $\mathrm{x}$ & $\mathrm{x}$ & & $\mathrm{x}$ & & $\mathrm{x}$ \\
\hline Mezgit Merlangus merlangus & $\mathrm{x}$ & $\mathrm{x}$ & $\mathrm{X}$ & $\mathrm{x}$ & $\mathrm{x}$ & $\mathrm{x}$ & $\mathrm{X}$ & $\mathrm{x}$ & $\mathrm{X}$ & $\mathrm{x}$ & $\mathrm{X}$ & $\mathrm{x}$ \\
\hline İskorpit Scorpaena porcus & $\mathrm{X}$ & $\mathrm{x}$ & $\mathrm{x}$ & $\mathrm{x}$ & & $\mathrm{x}$ & & $\mathrm{x}$ & & $\mathrm{x}$ & & $\mathrm{x}$ \\
\hline Kaya Gobius niger & & & & & & & & & $\mathrm{x}$ & & & $\mathrm{x}$ \\
\hline Yasal dönem & & & & & & & & & & & & \\
\hline $\begin{array}{l}\text { Yasal olmayan dönem (Dip Trolü: } \\
\text { Diğger av araçları ile yasal dönem }\end{array}$ & 5 Eyl & $15 \mathrm{~N}$ & $\mathrm{n}, \mathrm{Or}$ & u Tro & $15 \mathrm{Ey}$ & $15 \mathrm{~N}$ & $n$, Ç & & ar1: 1 & ylül- & Nisar & \\
\hline
\end{tabular}

Tablo 2 Balıkların üretim miktarı, iç piyasa miktarı ve fiyatı, 2008-2013

\begin{tabular}{l|lcccccc}
\hline Balık Türü & Üretim(ton)/Yıl & 2008 & 2009 & 2010 & 2011 & 2012 & 2013 \\
\hline \multirow{3}{*}{ Hamsi } & Üretim Miktarı & $251.675,0$ & $204.699,0$ & $229.023,0$ & $228.491,4$ & $163.981,9$ & $179.615,2$ \\
& İç piyasa Miktarı & $155.933,0$ & $114.488,0$ & $115.892,0$ & $100.883,5$ & $81.074,3$ & $103.424,8$ \\
& Fiyatı (TL) & 1,8 & 1,1 & 1,5 & 1,8 & 2,1 & 2,4 \\
\hline \multirow{3}{*}{ İstavrit } & Üretim Miktarı & $22.134,0$ & $20.373,0$ & $14.392,0$ & $18.072,7$ & $24.625,3$ & $21.817,8$ \\
& İç piyasa Miktarı & $22.134,0$ & $20.373,0$ & $14.392,0$ & $18.072,7$ & $24.625,3$ & $21.817,8$ \\
& Fiyatı (TL) & 3,0 & 2,5 & 3,7 & 3,8 & 3,7 & 4,3 \\
\hline \multirow{3}{*}{ Lüfer } & Üretim Miktarı & $4.048,0$ & $5.999,0$ & $4.744,0$ & $3.122,0$ & $7.389,5$ & $5.225,2$ \\
& İç piyasa Miktarı & $4.048,0$ & $5.999,0$ & $4.744,0$ & $3.122,0$ & $7.389,5$ & $5.225,2$ \\
& Fiyatı (TL) & 16,5 & 10,7 & 10,8 & 12,1 & 12,4 & 14,3 \\
\hline \multirow{3}{*}{ Palamut } & Üretim Miktarı & $6.448,0$ & $7.036,0$ & $9.401,0$ & $10.018,9$ & $35.764,2$ & $13.157,6$ \\
& İç piyasa Miktarı & $6.448,0$ & $7.036,0$ & $9.401,0$ & $10.018,9$ & $35.764,2$ & $13.157,6$ \\
& Fiyatı (TL) & 8,0 & 6,2 & 7,0 & 8,1 & 4,3 & 6,5 \\
\hline \multirow{3}{*}{ Kalkan } & Üretim Miktarı & 528.0 & 383,0 & 295,0 & 166,4 & 202,7 & 209,4 \\
& İç piyasa Miktarı & 528,0 & 383,0 & 295,0 & 166,4 & 202,7 & 209,4 \\
& Fiyatı (TL) & 24,0 & 26,4 & 30,1 & 35,2 & 39,8 & 44,8 \\
\hline \multirow{3}{*}{ Barbunya } & Üretim Miktarı & $1.925,0$ & $2.461,0$ & $2.351,0$ & $1.861,4$ & $2.453,1$ & $2.055,4$ \\
& İç piyasa Miktarı & $1.925,0$ & $2.461,0$ & $2.351,0$ & $1.861,4$ & $2.453,1$ & $2.055,4$ \\
& Fiyatı (TL) & 13,0 & 10,2 & 16,6 & 17,5 & 18,7 & 18,9 \\
\hline \multirow{3}{*}{ Mezgit } & Üretim Miktarı & 12231,0 & $11.146,0$ & $13.558,0$ & $9.454,8$ & $7.367,1$ & $9.396,9$ \\
& İç piyasa Miktarı & 12231,0 & $11.146,0$ & $13.558,0$ & $9.454,8$ & $7.367,1$ & $9.396,9$ \\
& Fiyatı (TL) & 3,6 & 2,4 & 4,4 & 5,5 & 6,1 & 6,8 \\
\hline
\end{tabular}

Tablo 2 incelendiğinde, hamsi dıșında diğer balıkların üretiminin tamamının iç piyasada tüketildiğini, balık fiyatlarının o yılda piyasada olan toplam miktarın tek başına etken olmadığını yıllık fiyat belirlemede bir önceki yıl ile mukayese yapılamayacağını, fiyatların balıkçılığın kendi dinamikleri içerisinde satış fiyatının belirlendiğini söylemek yanlış olmayacaktır.

Araştırma sürecinde Sinop'ta perakende satış yerlerinde satışa sunulan (Hamsi, İstavrit, Lüfer, Palamut, Kalkan, Barbunya, Mezgit) balıkların perakende satış fiyatları Tablo 3'de verilmiştir.

Ekonomik değeri yüksek olan bazı balık türlerinin satış fiyatlarını gösteren Tablo 3 incelendiğinde;

Hamsi: Ülke genelinde olduğu gibi yörede en çok tüketilen balıklar arasındadır. Hamsi, I.tip satış yerinde dönem boyunca bulunmasına rağmen, II.tip satıs yerinde genellikle ve III.tip satış yerinde sadece Kasım ve Aralık aylarında satıldığı belirlenmiştir. Şubat ve Nisan aylarında II. ve III.tip satış yerlerinde hamsi balığının fiyatının çok yüksek olması ve talebin az olacağı düşüncesi ile satışın olmadığı düşünülmektedir. Tabloda görüldüğü gibi hamsi balığı Kasım, Aralık aylarında diğer aylara göre daha ucuz olması nedeniyle tüm satış yerlerinde bulunduğu belirlenmiştir. Yasağın kalktığı Eylül ayında hamsinin tezgahlarda bulunmaması avcılığının yapılamamasından, Nisan ayında en yüksek fiyattan satılması ise balığın çok az miktarda avlanmasından kaynaklanmaktadır. Hamsi balığı fiyatı örnekleme istasyonları arasında farklılık göstermiştir $(\mathrm{P}<0,05)$. 
Tablo 3 Balıkların Perakende Satış Fiyatı (TL), 2008-2013

\begin{tabular}{|c|c|c|c|c|c|c|c|c|c|c|c|c|c|c|c|c|c|c|c|c|c|}
\hline \multirow[b]{5}{*}{ Ay } & \multicolumn{21}{|c|}{ Balık Türleri } \\
\hline & \multicolumn{3}{|c|}{ Hamsi } & \multicolumn{3}{|c|}{ İstavrit } & \multicolumn{3}{|c|}{ Lüfer } & \multicolumn{3}{|c|}{ Palamut } & \multicolumn{3}{|c|}{ Kalkan } & \multicolumn{3}{|c|}{ Barbunya } & \multicolumn{3}{|c|}{ Mezgit } \\
\hline & \multicolumn{21}{|c|}{ Satış Yerleri } \\
\hline & I & II & III & $\mathrm{I}$ & II & III & I & II & III & $\mathrm{I}$ & II & III & $\mathrm{I}$ & II & III & I & II & III & $\mathrm{I}$ & II & III \\
\hline & \multicolumn{21}{|c|}{2012} \\
\hline May. & - & - & - & 5,5 & 5,0 & 5,0 & - & - & - & - & - & - & - & - & - & 17,0 & 17,0 & 15,0 & 15,0 & 14,5 & 15,5 \\
\hline Haz. & - & - & - & 5,0 & 5,0 & - & - & - & - & - & - & - & - & - & - & 15,0 & 15,0 & 15,0 & 15,0 & 15,0 & 15,5 \\
\hline Tem. & - & - & - & 4.5 & - & - & - & - & - & - & - & - & - & - & - & - & - & - & 20,0 & 21,0 & 19,5 \\
\hline Ăgu. & - & - & - & 7,5 & 5,0 & 6,5 & 15,0 & 15,0 & - & 5,0 & 5,0 & 5,5 & - & - & - & 20,0 & 20,0 & - & 20,0 & 19,5 & 20,0 \\
\hline Eyl. & - & - & - & 5,0 & - & - & 15,0 & 12,5 & 10,0 & 4,5 & 4,5 & 4,8 & 60,0 & - & - & 9,0 & 11,0 & - & 7,5 & 8,0 & 7,5 \\
\hline Eki. & 5,0 & 5,0 & - & 4,3 & 4,5 & 4,8 & 12,0 & 22,5 & 13,5 & 7,5 & 7,0 & 6,8 & 35,0 & 30,0 & - & 14,0 & 15,0 & - & 5,0 & 5,5 & 5,5 \\
\hline Kas. & 4,3 & 7,0 & 4,0 & 3,5 & 6,5 & 4,5 & 13,5 & 14,5 & 15,0 & 6,8 & 6,5 & 5,8 & 42,5 & 50,0 & - & 14,0 & 30,0 & - & 5,0 & 4,5 & 5,0 \\
\hline Ara. & 4.0 & 4,0 & 4,3 & 4,0 & 4,0 & 4,3 & 15,0 & 7,0 & 15,0 & 6,0 & $\begin{array}{l}7,5 \\
201\end{array}$ & - & 60,0 & - & - & 10,0 & 15,0 & 10,0 & 7,5 & 7,0 & 7,5 \\
\hline Oca. & 5,0 & 4,0 & - & 5,3 & 4,3 & 4,0 & 20,0 & 10,0 & 10,0 & 8,0 & 5,0 & 10,0 & 60,0 & - & - & - & - & - & 8,0 & 7,5 & 5,5 \\
\hline Şub. & 10,0 & - & - & 4,0 & 5,0 & 5,3 & - & - & - & - & - & - & 65,0 & - & - & 12,0 & 15,0 & 15,0 & 7,5 & 8,0 & 9,0 \\
\hline Mar. & 5,0 & 6,0 & - & 5,3 & 5,0 & 4,0 & - & - & - & - & - & - & 65,0 & 80,0 & 40 & - & - & - & 7,5 & 5,0 & 7,0 \\
\hline Nis. & 11,0 & - & - & - & - & - & - & - & - & - & - & - & 57,5 & 55,0 & - & 30,0 & 25,0 & 23,0 & 10,0 & 9,5 & 9,0 \\
\hline & 6,32 & 5,20 & 4,13 & 4,98 & 4,92 & 4,78 & 15,08 & 13,85 & 12,7 & 6,29 & 5,92 & 6,55 & 55,63 & 53,75 & 0 & 15,67 & 18,11 & 15,60 & 10,67 & 10,42 & 10,54 \\
\hline Ort. & \pm & \pm & \pm & \pm & \pm & \pm & \pm & \pm & \pm & \pm & \pm & \pm & \pm & \pm & \pm & \pm & \pm & \pm & \pm & \pm & \pm \\
\hline & 0,91 & 0,58 & 0,13 & 0,34 & 0,24 & 0,29 & 1,10 & 1,13 & 1,13 & 0,56 & 0,51 & 0,92 & 3,86 & 10,28 & 00 & 2,11 & 1,98 & 2,08 & 1,57 & 1,64 & 1,60 \\
\hline
\end{tabular}

Istavrit: Özellikle hamsi balığının olmadığı veya yüksek fiyatlarda olduğu zamanlarda tüketimi artan istavrit balığı II.tip satış yerlerinde Eylül, III.tip satış yerlerinde Haziran ve Eylül aylarının dışında tüm zamanlarda satıldığ belirlenmiştir. Çevirme ağları ile avcılığın yasak olduğu dönemlerde uzatma ağları ve olta balıkçılığı ile avcılığın yapılması balığın tezgahlarda bulunmasını arttırmaktadır. Tablo 3'ün incelenmesinden de anlaşılacağı gibi perakende balık satış yerlerinde tespit edilen balık fiyatlarının, örnekleme istasyonları arasında ve aylara göre istavrit balığı fiyatı örnekleme istasyonları arasında farkl11lk göstermemiştir $(\mathrm{P}>0,05)$.

Lüfer: Çevirme ağlarıyla, yasal avlanma dönemi dışında, uzatma ağları ve olta balıkçıllğı ile avlanmaktadır. Aynı tür olmasına rağmen satış yerlerinde farklı boylarda çinekop, sarıkanat ve lüfer olarak satışa sunulan türün fiyatlandırılmasında ortalama değer alınmıştır. Lüfer balığı genel olarak çinekop, sarıkanat ve lüfer olarak Ağustos-Ocak aylarında satılmaktadır. Büyüklüğe göre fiyatlar arasında önemli farklılıklar belirlenmiş̧tir. Boy grupları bakımından küçükten büyüğe doğru fiyatlarda orantılı olmayan artış gözlenmektedir. Ayrıca, perakende balık satış yerlerinde tespit edilen fiyatların, örnekleme istasyonları arasında farklılık gösterdiği de tespit edilmiş̧ir. İstasyonlarda genel olarak çinekop, nadiren sarıkanat ve lüfer satışının olduğu, çinekopun 7,0-15,0 TL arasında, sarıkanat ise 15,0-22,5 TL arasında satışa sunulduğu belirlenmiştir. Aylara göre lüfer balığı fiyatı örnekleme istasyonları arasında farklılık göstermiş̧tir $(\mathrm{P}<0,05)$.

Palamut: Satış yerlerinde Ağustos ayının ikinci yarısından itibaren Ocak ayına kadar satışa sunulduğu belirlenmiştir. Palamut balığı, tüm perakende satış yerlerinde sezon boyunca satışa sunulmakta ve fiyatlarda çok fazla değişiklik göstermemektedir. Lüfer balığında olduğu gibi büyüklüğe göre fiyatlar arasında önemli farklılıklar belirlenmiştir. Boy grupları bakımından küçükten büyüğe doğru fiyatlarda orantılı olmayan artış gözlenmektedir. Tane olarak satışa sunulan palamut balığının en yüksek fiyatının 10,0 TL ile avcılığının azalmaya başladığı Ocak ayında, en düşük fiyatının ise 4,5 TL ile yoğun avcılığının yapıldığı Eylül ayında olduğu belirlenmiştir. Aylara göre palamut balığı fiyatı örnekleme istasyonları arasında farklılık göstermiştir $(\mathrm{P}<0,05)$.

Kalkan: Ülkemiz demarsal balık türleri içinde ekonomik olarak en değerli balıklarından birisidir. Kalkan balığı I.tip satış yerinde yasal avcılığın yapıldığı dönem boyunca bulunmasına rağmen, II. tip ve III. tip satış yerinde nadiren satıldığ 1 belirlenmiştir. Kalkan balığı nadiren avlanan, lezzetli olduğu kadar pahalı bir balıktır. $\mathrm{Bu}$ nedenle Tablo 3'de görüleceği üzere I.tip perakende satıs yerinde yasal av zamanında bulunmakla birlikte, II. ve III.tip satış yerinde nadiren bulunmaktadır. Aylara göre kalkan balığı fiyatı örnekleme istasyonları arasında farklılık göstermiştir $(\mathrm{P}<0,05)$.

Barbunya: Farklı av materyalleri ile y1lın her ayında avlanmakta olup, her üç satış yerinde de satılmaktadır. Barbunya balığının farklı av materyalleri ile avlanması farklı zamanlarda teminini kolaylaştırmaktadır. $\mathrm{Bu}$ nedenle bireysel ağırlık grubu balıklarına göre pahalı olmasına rağmen satış yerlerinde tercih edilen türlerdendir. Aylara göre barbunya balığı fiyatı örnekleme istasyonları arasında farklılık göstermemiştir $(\mathrm{P}>0,05)$.

Mezgit: Bölgede sevilerek tüketilen mezgit balığının 2008-2013 yılları arasındaki üretim miktarı, iç piyasa miktarı ve fiyatı Tablo 2'de verilmektedir. Farklı av materyalleri ile yılın her ayında avlanmakta olan mezgit balığının satış yerinde de satış olanağı bulmaktadır.

Y1llara dayalı fiyatlara bakıldığında 2012-2013 y1lı Sinop ili fiyatlarının 2008-2013 y1lı ortalama fiyatlarına göre; hamsi ve kalkan balık fiyatlarının yüksek olduğu, istavrit, lüfer, palamut, barbunya ve mezgit balığı fiyatlarının ise yakın olduğu tespit edilmiştir.

Yapılan çalışmada satış merkezlerinde Hamsi, İstavrit, Lüfer, Palamut, Tirsi, Zargana, Kefal, Eşkina, Kırlangıç, Kalkan, Barbunya, Mezgit, İskorpit, Minekop, Karagöz, İsparoz, İzmarit, Kaya balı̆ğ ve yetiştiricilik türlerinin satışının yapıldığı belirlenmiştir. Farklı av materyalleri ile avlanan türlerin yılın genelinde satışa sunulduğu, bazı 
türlerin ise tüketici tercihine bağlı olarak nadiren bulunduğu tespit edilmiştir.

Hamsi balığının bolluk durumuna bağlı olarak ekimocak ayları arasında 4,0-5,0 TL, şubat-nisan aylarında ise 10,0-11,0 TL gibi yüksek fiyatlara ulaşmaktadır. Daha fazla zaman aralığında temin edilen istavrit balığının ise hamsinin avcılığının olmadığı eylül ayında en yüksek fiyata ulaştığı, diğer aylarda ise 4,0-5,0 TL fiyat aralığında olduğu belirlenmiştir. Lüfer ve palamut balığının fiyatı daha öncede bahsedildiği gibi farklı boy gruplarında satışa sunulduğundan boy gruplarının bolluk durumuna göre değişmektedir. Ayrıca, palamut balığı piyasada adet (çift) olarak satıldığından değerlendirme zamana bağlı olarak yapılmıştır.

Kalkan balığının bolluk durumuna bağlı olarak ekim ve kasım aylarında nispeten düşük (32,5-46,5 TL), diğer aylarda ise 60,0-65,0 TL gibi yüksek fiyatlara ulaşmaktadır. Farklı av materyalleri ile avlanan ve daha geniş dönemlerde temin edilen barbunya ve mezgit balığının, trol dışındaki av materyalleri ile yakalandığında daha az miktarda olması nedeniyle yüksek fiyatlara çıktığı (Temmuz-Ağustos 20,0 TL), trol ile avlandığı dönemlerde ise arza bağlı olarak fiyatının düştüğü belirlenmiştir (Ekim-Kasım 5,0 TL).

Ekonomik değeri yüksek olan türlerden hamsi, lüfer, palamut ve kalkan balığının fiyatları örnekleme istasyonları arasında farklılık gösterirken $(\mathrm{P}<0,05)$, istavrit, barbunya ve mezgit balığının fiyatları farklılık göstermemiştir $(\mathrm{P}>0,05)$. Y1llara dayalı fiyatlara bakıldığında 2012-2013 yılı Sinop ili istavrit, lüfer, palamut, barbunya, mezgit balığ 1 fiyatlarının 2008-2012 yılı ortalama fiyatlarına yakın, hamsi ve kalkan balığı fiyatlarının ise yüksek olduğu tespit edilmiştir.

Sinop'ta perakende satış yerlerindeki balık türleri ve türlerin fiyatlarının belirlenmesinin amaçlandığı bu çalışmada, talep edilen balık türlerinin her zaman bulunmaması, büyüklüklerine bağlı olarak tercih edilen türlerin azlığı, arz miktarları ve satış yerlerinin sürekli müşterilerinin sosyo-ekonomik gelişmişliklerine bağlı olarak yeterli ve dengeli beslenme talepleri ve farklı yiyecek deseni oluşturmaları (Lorcu, 2012) fiyat farklılığ üzerinde etki gösterdiği düşünülmektedir.

Tüketicilerin tüketim talepleri ve ürün satın alış yeri tercihleri bakımından yapılan araştırmalarda; tüketicilerin balık satın alırken en önemli buldukları konuların başında, balığın tazeliği, satış yerinin temizliğinin öncelikli tercihler arasında olduğunu belirtmekle birlikte ucuz oluşuna da büyük önem vermektedirler (Kotler, 1997; Aydın ve Karadurmuş, 2012; Çiçek ve ark., 2013; Türkmen ve ark., 2016). Ayrıca ailelerin gelir seviyesinin balık satın alma tercihlerini etkileyen önemli faktörlerden arasında olduğu (Hatırlı ve ark., 2004), bu aktivitelerin yani pazara sunulan ürünün son değerlendirmesinin tüketici tarafından yapıldığı belirtilmiştir (Saygı ve ark., 2006).

Sonuç olarak; perakende balık satış yerleri arasında ki fiyat farkını önemli kılan hususlar yerel ve merkezi yönetimlerce alınacak tedbirlerle ortadan kaldırılmalıdır. Balıkçılık sektörünün iki ucunda yer alan satıcı ve tüketicilerin bilinç düzeylerinin artırılmasında, gerek tüketim alışkanlığı gerekse seçici ve denetleyici tüketici bilincinin kazandırılması için devlet ve özel sektör işbirliğinde eğitim kurumlarının yanında medyayı da paydaş olarak sisteme dâhil edecek projeler gerçekleştirilmelidir.

\section{Kaynaklar}

Arıtaşı C. 2009. Et ve Balık İşleme Teknolojisi Ders Notları, Namık Kemal Üniversitesi, Tekirdağ

Atar HH, Alçiçek Z. 2009. Su Ürünleri Tüketimi ve Sağlık. TAF Prev. Med. Bull. 8(2), 173-176.

Aydın M, Karadurmus U. 2012. Consumer Behaviours for Seafood in Ordu Province. Yunus Araştırma Bülteni, 2012 (3):18-23.

Büyüknisan O. 2008. Adana İli Kentsel Alanda Tavuk Eti Tüketim Yapısı. Ç.Ü. Fen Bilimleri Enstitüsü, Tarım Ekonomisi Anabilim Dalı, Yüksek Lisans Tezi, Adana.

Çiçek E, Akgün H, İlhan S. 2014. Elazığ İli Balık ti Tüketim Alışkanlığı ve Tercihinin Belirlenmesi. Yunus Araştırma Bülteni 2014 (1): 3-11.

Hanta B. 1994. Adana İli Kentsel Alanda Hayvansal Gıda Tüketim Yapısı. Ç.Ü. Fen Bilimleri Enstitüsü, Tarım Ekonomisi Anabilim Dalı, Yüksek Lisans Tezi, Adana.

Hatırlı SA, Demircan V, Aktaş AR. 2004. Isparta İlinde Ailelerin Balık Tüketiminin Analizi. Süleyman Demirel Üniversitesi İktisadi ve İdari Bilimler Fakültesi, Y.2004, C.9, S.1 s.245-256.

Kaba N, Çorapc1 B. 2014. Effects of Two Different Modified Atmosphere Compositions on

Durability of Steam-Cooked Rainbow Trout (Oncorhynchus Mykiss, Walbaum, 1792). Journal of Food Processing and Preservation, 38, 2155-2166. (DOI: 10.1111/jfpp.12195)

Kotler P. 1997. Marketing Management: Analysis, Planning, Implementation and Control.8th Prentice Hall, New Jersey.

Saygı H, Saka Ş, Fırat K, Katağan T. 2006. İzmir Merkez İlçelerinde Kamuoyunun Balık Tüketimi ve Balık Yetiştiriciliğine Yaklaşımı E.Ü. Su Ürünleri Dergisi, Cilt 23, Say1 (1-2): 133-138, İzmir.

TÜİK 2013. 2012 Y11 $\mathrm{Su}$ Ürünleri İstatistikleri, tuikapp.tuik.gov.tr/medas/?kn=97 \&locale=tr.

TÜIKK 2014. 2013 Y1l1 Su Ürünleri İstatistikleri, tuikapp.tuik.gov.tr/medas/?kn=97 \&locale=tr.

Türkmen M, Türkmen A, Duran K. 2016. Giresun İlinde Balık Tüketiminin Araştırılması. Türk Tarım-Gıda Bilim ve Teknoloji Dergisi, 4(8): 712-718, 2016 